Pesq. Vet. Bras. 29(3):266-274, março 2009

\title{
Thymic atrophy in cattle poisoned with Solanum glaucophyllum ${ }^{1}$
}

\author{
Paula A. Fontana², Carolina N. Zanuzzi²,3, Claudio G. Barbeito ${ }^{2,3}$ Eduardo J. \\ Gimeno², and Enrique L. Portiansky²*
}

\begin{abstract}
Fontana P.A., Zanuzzi C.N., Barbeito C.G., Gimeno E.J. \& Portiansky E.L. 2009. Thymic atrophy in cattle poisoned with Solanum glaucophyllum. Pesquisa Veterinária Brasileira 29(3):266-274. Facultad de Ciencias Veterinarias, Universidad Nacional de La Plata, Calle 60 y 118, 1900 La Plata, Argentina. E-mail: elporti@fcv.unlp.edu.ar

Solanum glaucophyllum $(\mathrm{Sg})[=S$. malacoxylon $]$ is a calcinogenic plant inducing "Enzootic Calcinosis" in cattle. The 1,25-dihydroxyvitamin $\mathrm{D}_{3}$, its main toxic principle, regulates bone and calcium metabolism and also exerts immunomodulatory effects. Thymocyte precursors from bone marrow-derived progenitor cells differentiate into mature T-cells. Differentiation of most $\mathrm{T}$ lymphocytes is characterized not only by the variable expression of CD4/CD8 receptor molecules and increased surface density of the $T$ cell antigen receptor, but also by changes in the glycosylation pattern of cell surface glycolipids or glycoproteins. Thymocytes exert a feedback influence on thymic non-lymphoid cells. Sg-induced modifications on cattle thymus T-lymphocytes and on non-lymphoid cells were analysed. Heifers were divided into 5 groups (control, intoxicated with $\mathrm{Sg}$ during 15,30 or 60 days, and probably recovered group). Histochemical, immunohistochemical, lectinhistochemical and morphometric techniques were used to characterize different cell populations of the experimental heifers. Sg-poisoned heifers showed a progressive cortical atrophy that was characterized using the peanut agglutinin (PNA) lectin that recognizes immature thymocytes. These animals also increased the amount of nonlymphoid cells per unit area detected with the Picrosirius technique, WGA and DBA lectins, and pancytokeratin and S-100 antibodies. The thymus atrophy found in intoxicated animals resembled that of the physiological aging process. A reversal effect on these changes was observed after suppression of the intoxication. These findings suggest that Sg-intoxication induces either directly, through the 1,25-dihydroxyvitamin $D_{3}$ itself, or indirectly through the hypercalcemia, the observed alteration of the thymus.
\end{abstract}

INDEX TERMS: Calcinosis; calcitriol, cattle, immunohistochemistry, lectinhistochemistry, plant poisoning, Solanum glaucophyllum, S. malacoxylon, thymus gland.

RESUMO.- [Atrofia do timo em bovinos intoxicados por Solanum glaucophyllum.] Solanum glaucophyllum $(\mathrm{Sg})[=S$. malacoxylon] é uma planta calcinogênica que induz "Calcinose Enzoótica" em bovinos. O 1,25-dihidroxivitamina D3, seu principal agente tóxico, regula o meta-

\footnotetext{
${ }^{1}$ Received on October 2, 2008.

Accepted for publication on November 12, 2008

2 Instituto de Patología, Facultad de Ciencias Veterinarias (FCV), Universidad Nacional de La Plata (UNLP), Calle 60 y 118, 1900 La Plata, Argentina. *Corresponding author: elporti@fcv.unlp.edu.ar

3 Departamento de Histología y Embriología, FCV-UNLP, 1900 La Plata, Argentina.
}

bolismo ósseo, o metabolismo de cálcio e também mostra efeitos na imunomodulação. Precursores de timócitos derivados da medula óssea se diferenciam em linfócitos T maduros. A diferenciação da maioria dos linfócitos T é caracterizada pela expressão variável de moléculas de receptores CD4/CD8 e densidade aumentada dos receptores antigênicos de superfície de células T. Alem disso, há mudanças no padrão de glicosilação de glicolipídeos na superfície celular ou de glicoproteínas. Timócitos mostram uma influência de retro alimentação em células tímicas não-linfóides. Foram analisadas modificações induzidas pelo $\mathrm{Sg}$ em linfócitos $\mathrm{T}$ e células tímicas nãolinfóides de bovinos. Novilhas foram divididas em 5 gru- 
pos (controle, intoxicadas com Sg durante 15, 30 ou 60 dias, e grupo provavelmente recuperado). As diferentes populações celulares das novilhas experimentais foram caracterizadas com técnicas histoquímicas, imunohistoquímicas, lectina-histoquímicas e morfométricas. As novilhas intoxicadas com Sg mostraram uma atrofia cortical progressiva que foi caracterizada usando a lectina aglutinina de amendoim (PNA) que reconhece timócitos imaturos. Estes animais também aumentaram as células não-linfóides tímicas por unidade de área, detectadas com a técnica de Picrosirius, lectinas WGA e DBA e anticorpos antipancitoqueratina e anti-S-100. A atrofia de timo observada nos animais intoxicados foi semelhante àquela do processo de envelhecimento fisiológico. Após supressão da intoxicação, foi observado um efeito de reversão nestas mudanças. Estes resultados sugerem que a intoxicação por Sg induza a alteração observada no timo diretamente, pela ação de 1,25-dihidroxivitamina D3, ou indiretamente, pela ação da hipercalcemia.

TERMOS DE INDEXAÇÃO: Calcinose, calcitriol, gado, imunohistoquímica, lectina-histoquímica, plantas tóxicas, intoxicação por planta, Solanum glaucophyllum, Solanum malacoxylon, timo.

\section{INTRODUCTION}

The thymus is a primary lymphoid organ in which bone marrow derived $T$ cell precursors undergo a complex process of maturation. Positively selected thymocytes leave the organ to populate $\mathrm{T}$ cell-dependent areas of peripheral lymphoid organs such as spleen, lymph nodes, Payer's patches, and tonsils (Anderson et al. 1996). Immature thymocytes, known as peanut agglutinin (PNA) positive cells, reside in the cortex of the thymus in a densely packed formation. During maturation and selection for Major Histocompatibility Complex antigen presentation thymocytes relocate into the thymic medulla becoming PNA negative cells (Reisner et al. 1976, Provvedini et al. 1989). This differentiation occurs along with cell migration in the context of the thymic microenvironment, a threedimensional network formed by epithelial cells, macrophages, dendritic cells, fibroblasts, and extracellular matrix components (Savino \& Dardenne 2000). The thymocytesnon lymphoid cells interactions are necessarily transient, since most microenvironmental cells are sessile elements whereas thymocytes migrate within the organ while differentiating (Ritter \& Palmer 1999).

Solanum glaucophyllum $(\mathrm{Sg})$ [= $S$. malacoxylon] is a plant with calcinogenic activity, that contains high levels of glycosides conjugates of $1,25(\mathrm{OH})_{2} \mathrm{D}_{3}$ or calcitriol as toxic principle (Corradino \& Wasserman 1974, Napoli et al. 1977). The chronic ingestion of Sg causes an intoxication state in bovine livestock, known as Enzootic Calcinosis (Worker \& Carrillo 1967, Gimeno et al. 2004). In the Enzootic Calcinosis, the excess of vitamin D stimulates calcium absorption thus inducing hypercalcemia. The excessively absorbed mineral cannot be physiologically accommodated, and the deposition in soft tissues results in calcinosis (Mello 2003).
In addition to its well known functions on mineral metabolism, calcitriol has several non-classical effects on growth and differentiation of many cell types and marked immunomodulatory properties (Deluca \& Cantorna 2001). This has led to investigate the possibility of using vitamin D compounds to suppress certain autoimmune disorders (Zella \& Deluca 2004) and to prevent both vascular and nonvascular transplant rejections (Hullet et al. 1998). Moreover, vitamin $\mathrm{D}$ deficiency affects the immune system, especially $T$ cell-mediated immunity, whereas vitamin $D$ excess actually suppresses certain functions of the immune system (Yang et al. 1993).

The above mentioned biological effects on the immune system are mediated by the vitamin $D$ nuclear receptor (VDR) (Veldman 2000). The presence of the VDR has been found in significant concentrations in most immune system cell types. Its highest concentration was detected in the immature immune cells of the thymus and in the mature $\mathrm{CD}^{+} \mathrm{T}$ lymphocytes (Deluca \& Cantorna 2001). Indeed, receptors for $1,25(\mathrm{OH})_{2} \mathrm{D}_{3}$ were identified in thymocytes isolated from bovines (Reinhardt et al. 1982), rats (Provvedini et al. 1984), mice (Ravid et al. 1984), and humans (Provvedini et al. 1987).

Taking into account the presence of such receptors in thymic cells it was of interest to the present study to determine structural and morphological changes of thymocytes as well as non-lymphoid cells in the thymus of Sg-poisoned cattle.

\section{MATERIALS AND METHODS}

\section{Plants and poisonous dose}

Solanum glaucophyllum $(\mathrm{Sg})$ leaves were collected from Enzootic Calcinosis incidence zones in Argentina. Leaves were air dried, powdered with a blender and orally administrated with tap water in individual doses of $25 \mathrm{~g} / \mathrm{kg}$ twice a week.

\section{Animals and experimental procedure}

Nine 2-year-old cross-bred (Aberdeen Angus-Holando Argentino) heifers were intoxicated with Sg either during 15 (I15), 30 (I-30) or 60 (I-60) days (experimental groups) and then sacrificed. Three more animals were intoxicated during 15 days but sacrificed after another 45 days (probably recovered group, $P R G)$. Another four animals were used as controls being sacrificed two at day 0 and another two after 60 days of the beginning of the experiment. The latter control just received tap water during intoxication time. Weekly clinical tests were performed to determine Enzootic Calcinosis classical signs (weight loss, stiffness, roughness of the hair coat and kyphosis). Animals were fed with hay and water ad libitum. They were housed at the experimental unit for one week prior to the experiment, in order to reduce stress effects due to transportation and environmental changes.

\section{Tissue samples}

Blood samples were obtained by jugular puncture twice a week, to determinate serum levels of calcium by spectrophotometry.

After sacrifice of the animals, complete necropsy was conducted. The thymus was carefully removed and weighed. 
Samples of the organ were fixed in $10 \%$ buffered formalin; paraffin embedded and cut in $5 \mu \mathrm{m}$ thick sections. Slides were routinely stained with haematoxylin and eosin for general observations. The picrosirius technique was performed to evaluate the amount of collagen per unit area (Portiansky et al. 2002).

A second set of paraffin-embedded sections mounted on slides coated with g-methacryloxypropyltrimethoxy-silane (Sigma Diagnostics, St Louis, MO, USA) were deparaffinised with xylene, incubated with $0.03 \%$ methanolic hydrogen peroxide during 30 minutes at room temperature to inhibit endogenous peroxidase activity, passed through graded alcohols and rinsed three times in deionised water and PBS. Slides were then incubated with antibodies or lectins according to the selected technique.

\section{Lectinhistochemistry}

To determine the different thymic subpopulations the carbohydrate expression pattern of the cells was analyzed. Lectinhistochemical studies were conducted as previously described (Cobo et al. 2004). Samples were incubated with biotinylated lectins during 2 hours, followed by incubation using the Avidin-Biotin-complex (ABC) technique (Vector Laboratories, Burlingame, CA, USA). The 3,3'diaminobenzidine tetrahydrocloride (DAB) (Dako, Carpinteria, CA, USA) was used as a chromogen and haematoxylin was employed for counterstaining. Seven lectins (Lectin Kit BK 1000; Vector) with different specificity were used, as follows: Con A (Concanavalia ensiformis, binding specificity $\alpha$-D-Man and -D-Glc); DBA (Dolichos biflorus, binding specificity $\alpha$-D-GalNAc); SBA (Glycine max, binding specificity $\alpha$-D-GalNAc, $\alpha$-D-GalNAc and $\alpha$ and $\beta$-Gal); PNA (Arachis hypogaea, binding specificity $\beta-\mathrm{D}-\mathrm{Gal}$ and (1-3)Gal Nac); RCA - I (Ricinus communis-I, binding specificity $\beta$-D-Gal and -D-Gal); UEA-1 (Ulex europaeus-I, binding specificity $\alpha$-L-Fuc); and WGA (Triticum vulgaris, binding specificity $\alpha$-D-GlcNAc and NeuNAc). The optimal lectin concentration was $30 \mu \mathrm{g} / \mathrm{ml}$ in PBS for all lectins, except PNA, which was applied at a concentration of $10 \mu \mathrm{g} / \mathrm{ml}$ (Goldstein \& Hayes 1978).

\section{Immunohistochemistry}

Anti pan-T antibody (Baq95A, VMRD, Inc. Washington, USA) used for identify thymocytes in cows, as previously described (Gutierrez et al. 1999) was used. Anti-human CD3, CD4, CD8 (prediluted) (Dako, Carpinteria, CA, USA) were used for detection of lymphocytes subpopulations in paraffin embedded bovine thymus. The following commercially available primary antibodies were used: monoclonal anti-human Pancytokeratin clone 5D3 and LP34 (CK) (prediluted) (Novocastra, Benton Lane, New Castle, UK); polyclonal rabbit anti-cow S-100 (prediluted) (Dako, Carpinteria, CA, USA). The immunohistochemical detection system was a dextran polymer based method (Universal EnVision ${ }^{\circledR}$ System, Dako) and was applied according to the manufacturers' instructions. The 3,3'diaminobenzidine tetrahydrochloride (DAB) (DakoCytomation) was used as a chromogen. Positively stained cells were considered those showing a dark golden brown DAB- $\mathrm{H}_{2} \mathrm{O}_{2}$ reaction product. Same tissues but without adding the primary antibody were used as negative controls. Haematoxylin was used for counterstaining.

\section{Image processing and analysis}

Histological images were obtained from a microscope (Olympus BX61 system microscope, Tokyo, Japan) with an objective of 40x, through an attached digital video camera (Evolution VF, QImaging, USA) and digitized in a 24 bit RGB, TIFF format using an image analysis software (ImagePro Plus v6.3 Media Cybernetics, USA). Twenty five images randomly selected per slide for each monoclonal antibody (CK, S100) or positively bound lectin were analyzed.

Immunostained or lectinstained cells were counted in each image based on the intensity of staining. For doing so the colour cube option of the measurement function of the program was issued. Mean number of cells per image was extrapolated to $\mathrm{mm}^{2}$. Data obtained was exported to a spreadsheet in order to perform statistical analysis. All the images were subjected to blinded routine counting by an experienced morphologist.

\section{Statistical analysis}

Morphometric data were statistically assessed by analysis of the variance (ANOVA). Bonferroni's test was used as a post hoc analysis. Differences with $P$ values $<0.05$ were considered as significant. Highly significant differences were defined as those with a $P$ value $<0.01$.

\section{Blood samples}

\section{RESULTS}

Serum calcium levels increased with intoxication time in I-15, I-30 and I-60 groups. Similarly, PRG increased its values during the 15 days of intoxication maintaining calcium levels within normal values similar to control group, after suppression of the intoxication (Fig.1).

\section{Thymus weight}

Typical lung and aortic calcifications were observed. Only the thoracic portion of thymus was found in the experimental groups. In the intoxicated animals, thymic weight decreased in a dose-dependent manner. Thymus of control group and PRG had similar weights (Table 1).

\section{Histological techniques}

Routine staining showed the typical histological structure of the non-involuted thymus in control animals. In the l-15 group, the amount of cells per unit area of the cortex was significantly reduced in comparison to controls (Fig.2A, Table 1). This was accompanied by a relative increase of the medullar area (Fig.2B). In I-30 and I-60

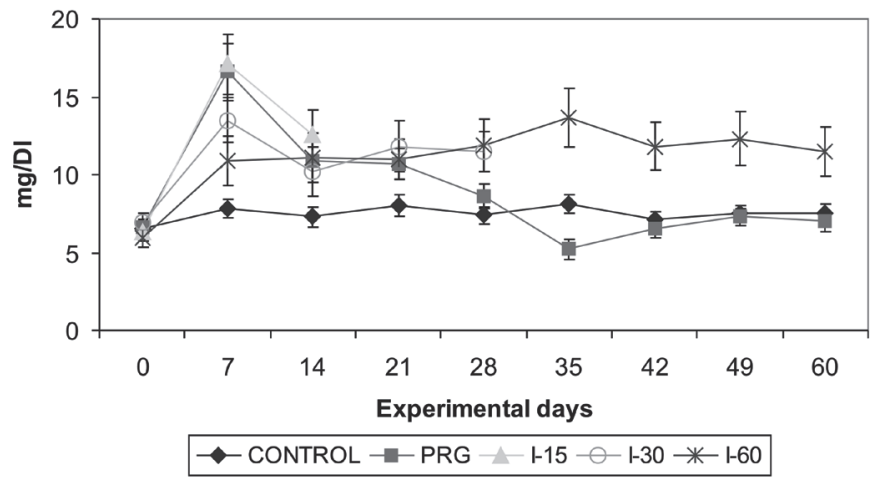

Fig.1. Serum calcium levels during poisoning with Solanum glaucophyllum $(\mathrm{Sg})$ [= S.malacoxylon]. A tendency to increase serum calcium levels was observed in poisoned animals. PRG increase its values during the poisoning period ( 15 days) and then began to drop down reaching the normal values registered for control animals. 
Table 1. Thymus weight and relative thymic areas in experimentally poisoned heifers

\begin{tabular}{|c|c|c|c|c|c|}
\hline $\begin{array}{c}\text { Anatomic } \\
\text { area }\end{array}$ & Control & $\mathrm{l}-15$ & $1-30$ & $\mathrm{I}-60$ & PRG \\
\hline & \multicolumn{5}{|c|}{ Absolute thymic weight (g) } \\
\hline & $220 \pm 15$ & $203 \pm 23$ & $165 \pm 13^{a}$ & $112 \pm 9^{a, b, c}$ & $214 \pm 11$ \\
\hline & \multicolumn{5}{|c|}{ Relative surface area (\%) } \\
\hline Cortex & $73.38 \pm 1.03$ & $65.59 \pm 2.75^{d}$ & $34.37 \pm 2.202^{b, d}$ & $03.28 \pm 1.24^{b, c, d}$ & $71.66 \pm 4.49$ \\
\hline Medulla & $22.44 \pm 2.33^{\mathrm{c}, \mathrm{e}}$ & $30.11 \pm 2.51^{\mathrm{c}, \mathrm{e}}$ & $49.78 \pm 5.23$ & $47.00 \pm 2.50$ & $25.23 \pm 3.95^{\mathrm{c}, \mathrm{e}}$ \\
\hline $\begin{array}{l}\text { Connective } \\
\text { tissue }\end{array}$ & $04.18 \pm 1.35^{\mathrm{c}, \mathrm{e}}$ & $04.30 \pm 2.83^{\mathrm{c}, \mathrm{e}}$ & $15.85 \pm 5.03^{\mathrm{e}}$ & $49.72 \pm 3.72$ & $03.11 \pm 1.95^{\mathrm{c}, \mathrm{e}}$ \\
\hline
\end{tabular}

Numbers indicate mean percentage $\pm \mathrm{SD}$. $\mathrm{P}<0.001$ in all cases. ${ }^{a}$ Significant vs. control and PRG; $b$

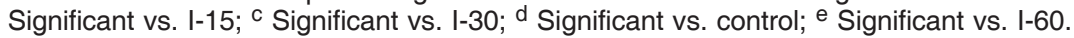
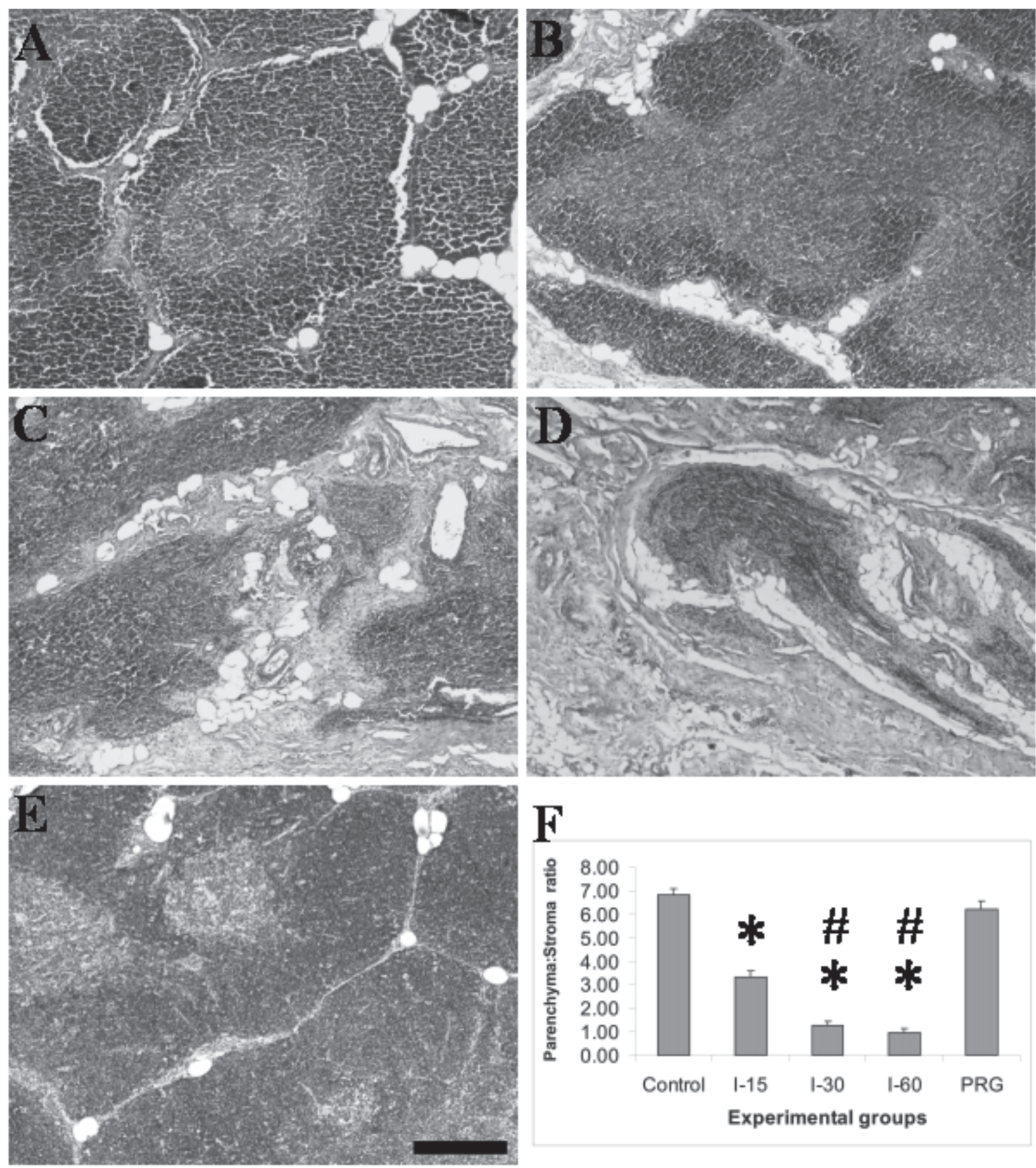

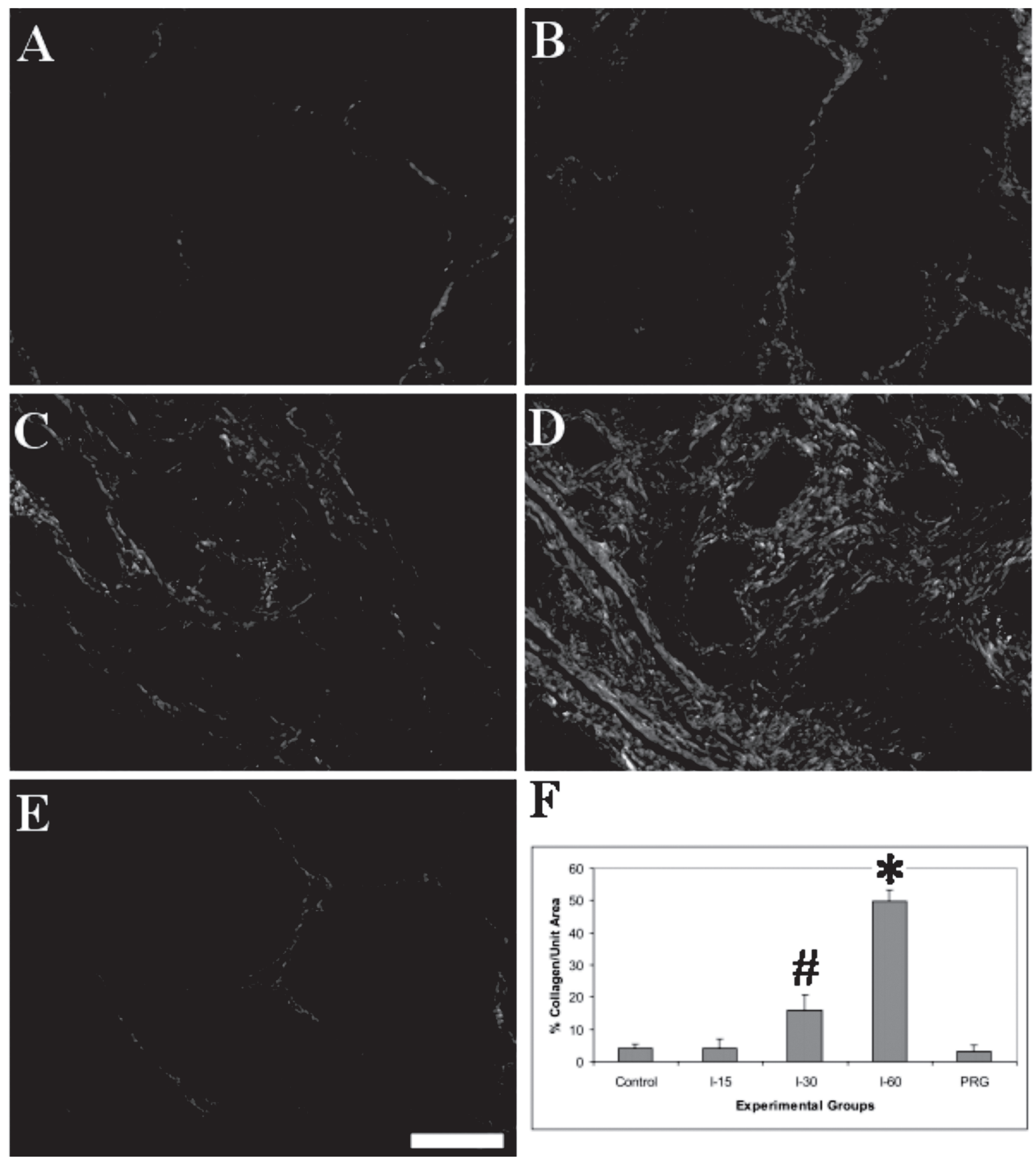

Fig.3. Collagen pattern in Sg-poisoned thymus. Connective tissue invades not only the extralobulillar zone but the intralobulillar zone while atrophy was in progress $(\mathbf{B}, \mathbf{C}, \mathbf{D})$ as was detected by the picrosirius technique. No variations were observed between the control group (A) and PRG (E). * I-60 significant vs. the remaining groups. \# I-30 significant vs. control, I-15 and PRG $(p<0.01)$. Picrosirius technique. Bar $=300 \mu \mathrm{m}$, obj.4x.

Fig.2. Histological changes of Sg poisoned thymus. (A) Architecture of the thymus in the control group. * Cortex; \# medulla. Histological aspect of the thymus in the poisoned groups (I-15, I-30, I-60) (B,C,D, respectively) showing a progressive cortical atrophy with proliferation of connective and adipose tissues. Note that different zones in I-30 and I-60 groups became indistinguishable with intoxication time. PRG showed architecture similar to control group (E). The ratio parenchyma:stroma showed significant differences between groups (F). * I-15, I-30 and I-60 vs control and PRG, \# I-30 and I-60 vs control and PRG. Haematoxylin and eosin. Bar $=300 \mu \mathrm{m}$, obj.4x. 

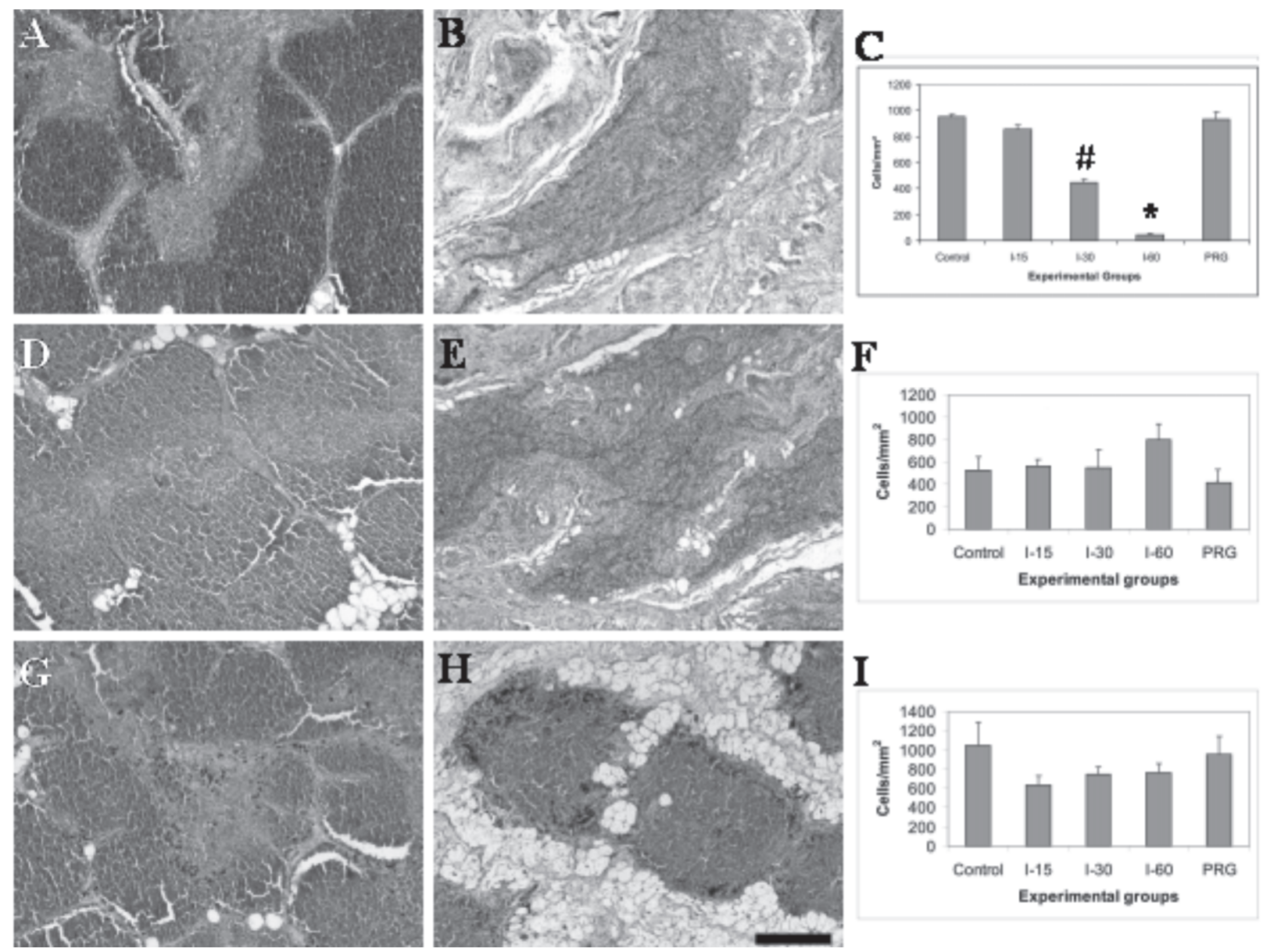

Fig.4. Lectinhistochemical pattern of Sg-poisoned thymus. Control (A,D,G) and I-60 (B,E,H) groups were incubated either with PNA (A,B), WGA (D,E) or DBA $(\mathbf{G}, \mathbf{H})$. PNA showed high affinity to cortical thymocytes. Lower amount of staining of cells can be observed in poisoned tissues. These differences were significant for I-60 vs. the remaining groups $\left(^{*}\right)$ and for I-30 vs. control, l-15 and PRG (\#) $(p<0.01)(\mathbf{C})$. WGA bound to the cytoreticular network and showed the relative increment of the non-lymphoid cells in intoxicated groups $(\mathbf{F})$. These differences were not significant. DBA bound to a specific cell subpopulation (macrophages) mainly located in the cortico-medullar junction and in the stroma. These cells were also found in the intoxicated animals and no significant differences were observed between groups (I). Avidin-Biotin-complex (ABC) technique with haematoxylin counterstaining. Bar $=300 \mu \mathrm{m}$, obj.4x.

groups (Fig.2C and D) the mentioned areas were difficult to define, therefore were characterized either by lectinhistochemistry (to define cortical and medullar areas) or the picrosirius technique. PRG behaved as controls (Fig.2E). Comparing the parenchyma:stroma ratio, significant differences were found between experimental groups (Fig.2F).

The picrosirius technique was used to confirm that in intoxicated animals the stroma showed a gradual relative increase, due to the extensive collapse of lymphoid content. Changes observed in I-60 and I-30 were significantly different in comparison to the other groups (Table 1). The histological aspect of the relative increase in the collagen fraction in the intoxicated animals can be seen in Figures $3 B, C$ and D. Collagen in PRG was similar to that observed in the control group (Fig.3A and E). 3F shows differences between groups.

\section{Lectinhistochemistry}

No changes in the glycosilation pattern were observed between normal and intoxicated bovines. Nevertheless, some lectins were useful for differentiate thymus populations. Thus, PNA, WGA and DBA were the only three out of the seven used lectins that produced remarkable outcomes. PNA showed a high affinity for cortical thymocytes. Even though all the cortical cells of all the analyzed groups were stained, this lectin served as confirmatory for the progressive cortical atrophy suffered by the intoxicated animals (Fig.4A-B). Although in control animals cortical thymocytes were also easily detected when stained with haematoxylin and eosin, in the intoxicated groups this identification was extremely difficult due to the disordered pattern that resulted when the parenchyma collapsed and mixed with the thymic stroma. In this sense, the positive reaction with PNA was very useful. Significant differences 

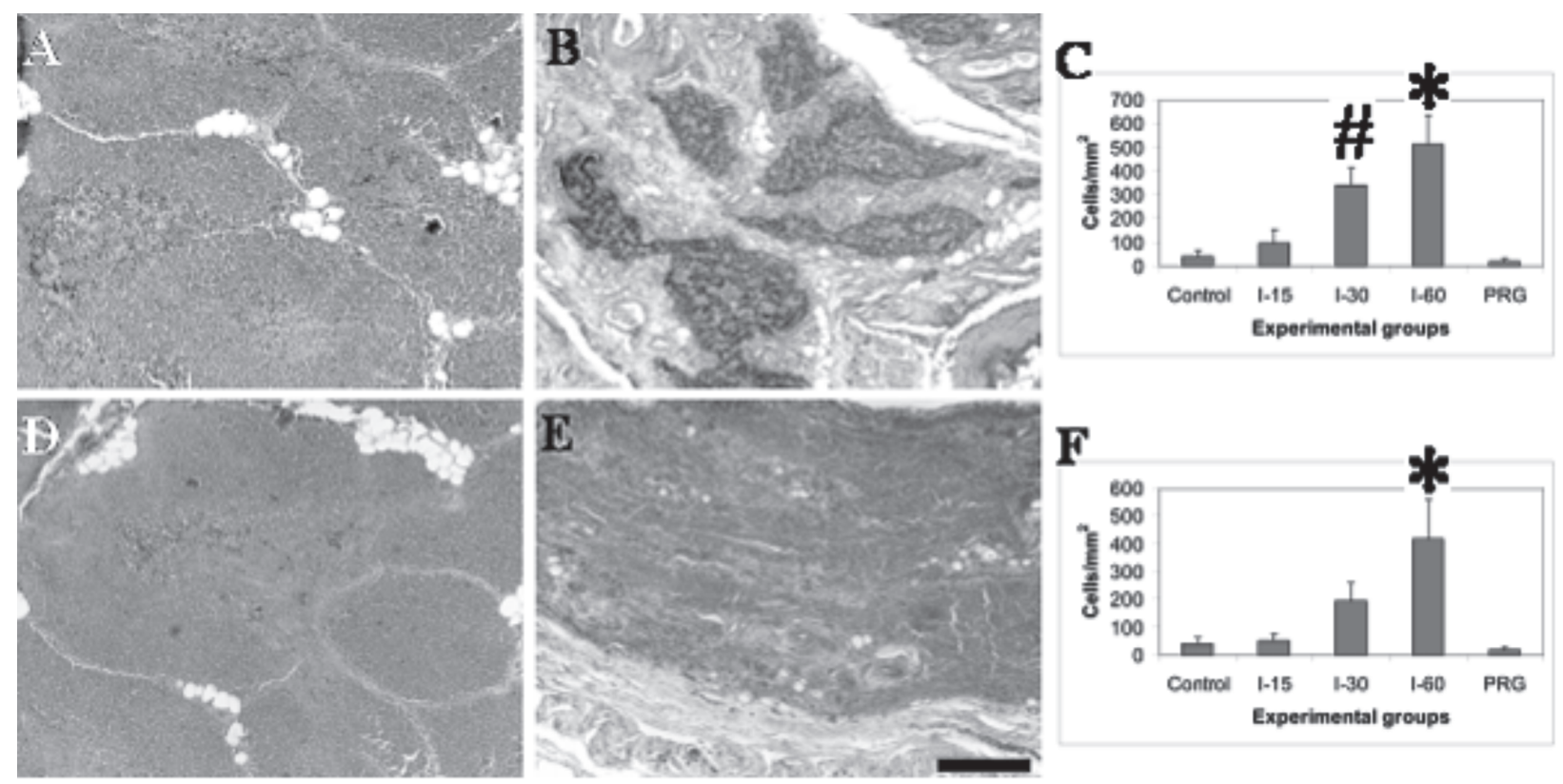

Fig.5. Immunohistochemical pattern of Sg-poisoned thymus. Control (A,D) and I-60 (B,E) groups. Both, CK (A, B) and $\mathbf{S 1 0 0}(\mathbf{D}, \mathbf{E})$, highly stained I-60 group non-lymphoid populations in comparison to the control group. Highly statistical differences $(\mathbf{C})$ were observed between I-60 vs control, I-15 and PRG $\left(^{*}\right)$ and I-30 vs control and PRG $(\#)(p<0.01)$ when thymus were incubated with CK antibodies while I-60 vs control, I-15 and PRG $\left(^{*}\right)(p<0.01)$ when stained with S100. Dextran polymer based method. Haematoxylin was used for counterstaining. Bar $=$ $300 \mu \mathrm{m}$, obj.4x.

between control and PRG in relation to I-15, I-30 and I-60 groups were observed (Fig.4C and Table 1).

WGA bound to the cortical and medullar cytoreticular networks (Fig.4D-E). The lectin-binding staining area showed an increase with intoxication time in comparison to the control group and the PRG. However, no significant differences were observed between groups (Fig.4F).

DBA showed affinity to macrophages, mainly localised in the cortico-medullar junction and in the connective tissue (Fig.4G-H). Although no statistically significant, the number of stained cells was greater in intoxicated heifers (Fig.4l). The remaining analyzed lectins did show neither cell specificity nor area affinity in both normal and intoxicated heifers.

\section{Immunohistochemistry}

The anti pan-T antibody was incubated with the experimental tissues to identify $T$ lymphocytes present in the thymus. Unfortunately, the specific antibody did not cross reacted with the bovine tissues as was previously reported (Gutierrez et al. 1999). CK and S-100 antibodies were used to identify different non lymphoid population present in the thymus. CK had similar staining pattern as that observed for the lectin WGA. The CK staining area was progressively enlarged with the intoxication time (Fig.5A-B). PRG showed the same normal distribution as the control group. The described changes in the CK stained area led to statistical differences between groups (Fig.5C).

Incubation with the S-100 antibody revealed the presence of non-lymphoid positive cells, mainly localised in the medullar region and in some cortical sectors (Fig.5D).
As was observed for $\mathrm{CK}$, the S-100 staining was increased with intoxication time (Fig.5E), showing again significant differences between groups (Fig.5F).

\section{DISCUSSION}

The thymus is a highly sensitive organ to many factors and substances under either physiological or pathological conditions (Schuurman et al. 1994). Both, the lymphoid compartment of the thymus (i.e., thymocytes) and the nonlymphoid compartment (consisting among others of epithelial and interdigitating cells, macrophages, and fibroblasts) can be target populations for such conditions. The structural changes observed in the Sg-intoxicated animals resembled those produced under physiological aging process of the organ (Steinmann 1986). This was coincident with in vivo experimental studies showing that excessive vitamin-D activity and altered mineral-ion homeostasis could accelerate the aging process (Razzake \& Lanske 2006). Working with these animals led us to determine a reduction of thymic weight. Alteration of the percentages of the relative areas of the organ due to a progressive cortical atrophy, and a relative increase of connective tissue with loss of the cortex-medullar junction was also observed. The cortical atrophy can be explained by the progressive reduction of PNA positive immature thymocytes $\left(\mathrm{CD} 4^{+} / \mathrm{CD} 8^{+}\right)$. PNA reactivity of immature thymocytes was already described in several studies (Reisner et al. 1976, Wu et al. 1996, Amado et al. 2004). The cortical atrophy was also described in in vivo studies performed in mice treated with $1,25(\mathrm{OH})_{2} \mathrm{D}_{3}$ (Mohamed et 
al. 1996). In these animals the atrophy was predominantly recorded in the cortical layer. It was suggested by the authors that the observed atrophy could be ascribed to the effect of hypercalcemia rather than to the $1,25(\mathrm{OH})_{2} \mathrm{D}_{3}$. On the other hand, Deluca \& Cantorna (2001) described that $\mathrm{CD} 4^{+} / \mathrm{CD}^{+}$cells are a calcitriol target population, due to its high concentration in VDR. It is thus apparent that both, $1,25(\mathrm{OH})_{2} \mathrm{D}_{3}$ released by $\mathrm{Sg}$ and the hypercalcemia it induces may be the reasons of the thymic atrophy observed in heifers.

The changes in the number of the non-lymphoid populations were previously described (Brekelmans \& van Ewijk 1990, Milicevic \& Milicevic 1998). In the intoxicated animals, an increase of $\mathrm{CK}^{+}$cells per unit area and of the other non-lymphoid populations was observed. This modification in the number of cells could be a direct consequence of the $1,25(\mathrm{OH})_{2} \mathrm{D}_{3}$ activity or relative to the reduction in the number of cortical thymocytes. As discussed by Elmore (2006), the loss of thymocytes can result in the epithelial component of the thymus appearing more prominent, but not necessarily with an increase in the number or size of epithelial cells. Even though VDR was described in non-lymphoid thymic rat cells (Stumpf \& Downs 1987), it has not been demonstrated in bovines. Therefore, we speculate that a combination of direct and indirect $1,25(\mathrm{OH})_{2} \mathrm{D}_{3}$ effects could be the responsible of the increment of the non-lymphoid compartment of Sgintoxicated heifers, per unit area.

We have found a reversal of thymic atrophy in the PRG. Hirokawa et al. (1992) and Henson et al. (2004) have stated that under certain circumstances the atrophy of the thymus could be reversed. Our findings are coincident with these studies and contribute to stress the concept that thymus is a dynamic immune organ, and if the etiological agent is eliminated from the body, the morphology of the thymus returns to a normal state thereafter.

The present data indicate that Sg-intoxication induces several effects on the immune system that alter the normal structure of the cattle thymus. The observed histopathological changes are highly relevant to determine the evolution of the toxic effect. In the experimental groups, atrophy of the organ cortex with reduction in the number of lymphoid cells and a relative increase in non-lymphoid cells, similar to age-related involution, was observed. All these changes were reversed after suppression of the intoxication.

Acknowledgements.- To Mrs. Rosa Villegas and Mr. Ruben Mario for their technical assistance. Financial support was provided in part by grants from "Agencia Nacional de Promoción Científica y Tecnológica" (ANPCyT), "Consejo Nacional de Investigaciones Científicas y Técnicas (CONICET)" and "Academia Nacional de Agronomía y Veterinaria" (ANAV), Argentina. All the authors are members of CONICET.

\section{REFERENCES}

Anderson G., Moore N.C., Owen J.J. \& Jenkinson E.J. 1996. Cellular interactions in thymocyte development. Ann. Rev. Immunol. 14:73-99.

Amado M., Yan Q., Comelli E.M., Collins B.E. \& Paulson J.C. 2004.
Peanut agglutinin high phenotype of activated CD8 T cells results from de novo synthesis of CD45 glycans. J. Biol. Chem. 279:689-697.

Brekelmans P. \& van Ewijk W. 1990. Phenotypic characterization of murine thymic microenvironments. Seminars Immunol. 2:13-24.

Cobo E.R., Campero C.M., Gimeno E.J. \& Portiansky E.L. 2004. Lectin binding patterns and immunohistochemical antigen detection in the genitalia of Tritrichomonas foetus-infected heifers. J. Comp. Pathol. 131:127-134.

Corradino R.A. \& Wasserman R.H. 1974. 1,25-dihydroxycholecalciferollike activity of Solanum malacoxylon extract on calcium transport. Nature 252:716-718.

Deluca H.F. \& Cantorna M.T. 2001. Vitamin D: Its role and uses in immunology. FASEB J. 15:2579-2585.

Elmore S.A. 2006. Enhanced histopathology of the thymus. Toxicol. Pathol. 34:656-665.

Gimeno E.J., Portiansky E.L., Gomar M.S., Costa E.F., Massone A.R., Alonso C.R., Dallorso M.E. \& Barros S.S. 2004. Calcinosis in ruminants due to plant poisoning: Contributions on the pathogenesis, p.84-89. In: Acamovic T., Stewart C.S. \& Pennycott T.W. (Ed.), Poisonous Plants and Related Toxins. Commonwealth Agricultural Bureau, Wallingford, UK.

Goldstein I.J. \& Hayes C.E. 1978. The lectins: carbohydrate-binding proteins of plants and animals. Adv. Carbohydr. Chem. Biochem. 35:127-340.

Gutierrez M., Forster F.I., McConnell S.A., Cassidy J.P., Pollock J.M. \& Bryson D.G. 1999. The detection of CD2+, CD4+, CD8+, and WC1+ T lymphocytes, B cells and macrophages in fixed and paraffin embedded bovine tissue using a range of antigen recovery and signal amplification techniques. Vet. Immunol. Immunopathol. 71:321-334.

Henson S.M., Pido-Lopez J. \& Aspinall R. 2004. Reversal of thymic atrophy. Exp. Gerontol. 39:673-678.

Hirokawa K., Utsuyama M., Kasai M. \& Kurashima C. 1992. Aging and immunity. Acta Pathol. Jap. 42:537-538.

Hullet D.A., Cantorna M.T., Redaelli C., Humpal-Winter J., Hayes C.E., Sollinger H.W. \& Deluca H.F. 1998. Prolongation of allograft survival by 1,25-dihydroxyvitamin $D_{3}$. Transplant. 66:824-828.

Mello J.R. 2003. Calcinosis. Calcinogenic plants. Toxicon 41:1-12.

Milicevic N.M. \& Milicevic Z. 1998. Cyclosporin A-induced changes of the thymic microenvironment. A review of morphological studies. Histol. Histopathol. 13:1183-1196.

Mohamed M.I., Beckman M.J., Meehan J. \& Deluca H.F. 1996. Effect of 1,25-dihydroxyvitamin $D_{3}$ on mouse thymus: Role of extracellular calcium. Biochem. Bioph. Acta 1289:275-283.

Napoli J.L., Reeve L.E., Eisman J.A., Schnoes H.K. \& Deluca H.F.1977. Solanum glaucophyllum as source of 1,25-Dihydroxyvitamin D3. J. Biol. Chem. 252:2580-2583.

Portiansky E.L., Alonso C.R., Costa E.F. \& Gimeno E.J. 2002. Collagenous and elastic system fibres in the aorta of cattle poisoned by Solanum glaucophyllum. Vet. Rec. 150:42-45.

Provvedini D.M., Deftos L.J. \& Manolagas S.C. 1984. 1,25dihydroxyvitamin $D_{3}$ receptors in a subset of mitotically active lymphocytes from the rat thymus. Biochem. Bioph. Res. Comm. 121:277-283.

Provvedini D.M., Rulot C.M., Sobol R.E., Tsoukas C.D. \& Manolagas S.C. 1987. 1Alpha,25-dihydroxyvitamin $D_{3}$ receptors in the human thymic and tonsillar lymphocytes. J. Bone Min. Res. 2:239-247.

Provvedini D.M., Sakagami Y. \& Manolagas S.C. 1989. Distinct target cells and effects of $1 \alpha, 25$-dihydrxyvitamin $\mathrm{D}_{3}$ and glucocorticoids in the rat thymus gland. Endocrinol. 124:1532-1538.

Ravid A., Koren R., Novogrodsky A. \& Liberman U.A. 1984. 1,25dihydroxyvitamin $D_{3}$ inhibits selectively the mitogenic stimulation of mouse medullary thymocytes. Biochem. Bioph. Res. Comm. 123:163-169.

Razzaque M.S. \& Lanske B. 2006. Hypervitaminosis D and premature 
aging: lessons learned from Fgf23 and Klotho mutant mice. Trends Mol. Med. 12:298-305.

Reinhardt T.A., Horst R.L., Littledike E.T. \& Beitz D.C. 1982. 1,25dihydroxyvitamin $D_{3}$ receptor in bovine thymus gland. Biochem. Bioph. Res. Comm. 106:1012-1018.

Reisner Y., Linker-Israeli M. \& Sharon N. 1976. Separation of mouse thymocytes into two subpopulations by the use of peanut agglutinin. Cell. Immunol. 25:129-134.

Ritter M.A. \& Palmer D.B. 1999. The human thymic microenvironment: new approaches to functional analysis. Seminars Immunol. 11:13-21.

Savino W. \& Dardenne M. 2000. Neuroendocrine control of thymus physiology. Endocr. Rev. 21:412-443.

Schuurman H.J., Kupe C.F. \& Vos J.G. 1994. Histopathology of the immune system as a tool to assess immunotoxicity. Toxicol. 86:187-212.

Steinmann G.G. 1986. Changes in the human thymus during ageing. In: Muller-Hermelinlk H.K. (Ed.), The Human Thymus. Curr. Topics Pathol. 75:43-88.
Stumpf W.E. \& Downs T.W. 1987. Nuclear receptors for $1,25(\mathrm{OH})_{2}$ vitamin $D_{3}$ in thymus reticular cells studied by autoradiography. Histochem. 87:367-369.

Veldman C.M., Cantorna M.T. \& Deluca H.F. 2000. Expression of 1,25dihydroxyvitamin $D_{3}$ receptor in the immune system. Arch. Biochem. Biophy. 374:334-338.

Worker N.A. \& Carrillo B.J. 1967. "Enteque seco", calcification and wasting in grazing animals in Argentina. Nature 215:72-74.

Wu W. Harley P.H., Punt J.A., Sharrow S.O. \& Kearse K.P. 1996. Identification of CD8 as a Peanut Agglutinin (PNA) receptor molecule on immature thymocytes. J. Exp. Med. 184:759-764.

Yang S., Smith C. \& Deluca H.F. 1993. 1,25-dihydroxyvitamin $D_{3}$ and 19-nor-1,25-dihydroxyvitamin $D_{3}$ suppress immunoglobulin production and thymic lymphocyte proliferation in vivo. Biochem. Biophys. Acta 1158:269-286.

Zella J.B. \& Deluca H.F. 2004. Vitamin D and autoimmune diabetes. J. Cell. Biochem. 88:216-222. 